section is valid in terms of both hypotheses since the gene and its 'tap' would be very closely linked. We have chosen to develop the 'substitution' hypothesis in greater detail because it is based on fewer assumptions than the 'tap' hypothesis.

\section{Summary}

We propose that thalassæmia is a mutation of either the $\alpha$ or the $\beta$ hæmoglobin gene, of the same kind as that observed in the abnormal adult hæmoglobins, but without effect on the electrophoretic behaviour of the protein. Such mutations would be expected to reduce, sometimes to nothing, the rate of production of that hæmoglobin.

We are grateful to Dr. Park Gerald, Boston, and Dr. H. Lehmann, London, for the help of many stimulating discussions. We wish to express our thanks to the Medical Foundation, Inc., Boston, for a grant, and to the National Institutes of Health for a fellowship (A. O. W. S.).

${ }^{1}$ Ingram, V. M., CIBA Found. Symp. on Human Genetics, Naples (1959)

"Itano, H. A., in "Abnormal Hæmoglobins", 12, Jonxis and Delafresnaye, editors (Blackwell, 1959).

${ }^{3}$ Rich, A., Proc. U.S. Nat. Acad. Sci., 38, 187 (1952).

${ }^{4}$ Valentine, W. N., and Neel, J. V., Arch. Int. Med., 74, 185 (1944).

${ }^{5}$ Kaplan, E., and Zuelzer, W., J. Lab. and din. Med., 36, $517(1950)$

${ }^{6}$ Kunkel, B. G., and Bearn, A. G., Fed, Proc., 16, 760 (1957).

? Kunkel, H. G., Ceppellini, R., Múller-Eberhard, V., and Wolf, J. J. Clin. Invest., 36, 1615 (1957)

${ }^{8}$ Gerald, P. S., and Diamond, L. K., Blood, 13, 61 (1958).

${ }^{9}$ Itano, H. A., "Adv. Prot. Chem.", 12, 215 (1952).

${ }^{10}$ Itano, H. A., "Ann, Rev. Biochem.", 25, 331 (1956)

${ }^{11}$ Itano, H. A., Amer. J. Human Genet., 5, 34 (1953).

${ }^{12}$ Kunkel, H. G., and Wallenius, G., Science, 122, 288 (1955). ${ }^{13}$ Rhinesmith, H. S., Schroeder, W. A., and Pauling, L., J. Amer.
${ }^{12}$ Rhinesmith, H. S., Schroeder, W. A., and Martin, N., J. Amer. Chem. Soc., 80, 3358 (1958).

${ }^{15}$ Perutz, M. F., Liquori, A. M., and Eirich, F., Nature, 167, 929 (1951).

${ }_{18}$ Perutz, M. F., Endeavour, 17, 190 (1958)

12 Hunt, J. A., Nature, 183, 1373 (1959).

${ }^{18}$ Jones, R. T., Schroeder, W. A., and Vinograd, J. R., J. Amer. Chem. Soc., 81, 4749 (1959).

${ }^{19}$ Schwartz, H. C., Spaet, T. H., Zuelzer, W. W. Neel, J. V., Robinson, A. R., and Kaufmann, S. F., Blood, 12, 238 (1957).

${ }^{20}$ Smith, E., and Torbert, J. V., Bull. Johns Hopkins Hosp., 101, 38 (1958).

${ }^{21}$ Ingram, V. M., Nature, 183, 1795 (1959).

${ }^{22}$ Singer, S. J., and Itano, H. A., Proc. U.S. Nat. Acad. Sci., 44, 522 (1958). ${ }^{23}$ Vinograd, J. R., Hutchinson, W. D., and Schroeder, W. A., J. Amer.
Chem. Soe., 81, 3168 (1959).

${ }^{24}$ Ingram, V. M., Nature, 178, 792 (1956).

${ }^{25}$ Silvestroni, E., and Bianco, I., Blood, 7, 429 (1952).

${ }^{28}$ Neel, J. V., Blood, 6, 389 (1951).

${ }^{27}$ Ceppellini, R., cited in Neel, J. V., "Hemoglobin" (National Research Council, washington, 1958).

2s Jones, R. T., Schroeder, W. A., Balog, J. E., and Vinograd, J. R.,

Aature, 178, 1055 (1956)

Bingle, J. P., Huehns, E. R., and Prankerd, T. A. J., Brit. Med. J., 1389 (1958).

"Gerald, P. S., in "Hemoglobin" (National Research Council,

${ }^{32}$ Fessas, P., in "Abnormal Hæmnglobins", 153, Jonxis and Delafresnaye, editors (Blackwell, 1959). ${ }^{33}$ Cohen, F., Zuelzer, W. W., Neel, J. V., and Robinson, A. R., Rlood,
14, 816 (1959).

${ }^{34}$ Zuelzer, W. W,, Neel, J. V., and Robinson, A. R., "Progress in Hematology;', 1, 91 (Grune and Stratton, J.956).

${ }^{5}$ Singer, KK., Kraus, A. P., Singer, I., Rubinstein, H. M., and Gold berg, S. R., Blood, 8, 1032 (1954).

${ }^{36}$ Zuelzer, W. W., and Kaplan, E., Blood, 9, 1047 (1954).

"Zuelzer, W. W., in "Abnormal Hæmoglobins", 199, Jonxis and Delafresnaye, editors (Blackwell, 1959).

${ }^{38}$ Singer, K., Josephson, A. M., Singer, L., Heller, P., and Zimmermann, H. J., Proc. Sixth Int. Cong. Int. Soc. Hemat. (Boston, 1956). Grune and Stratton.

${ }^{39}$ Ceppellini, R., Symp. Geneticae Hæmatologicae in VII Congres Int. Soc. Hrmatol., 47 (Rome, 1958).

${ }^{40}$ Freese, E., Cold Spring Harbor Symp. Quant. Biol., 23, 13 (1958).

\title{
INTERNATIONAL MINERALOGICAL ASSOCIATION
}

\section{FIRST GENERAL MEETING}

$\mathrm{M}$ INERALOGISTS from nineteen countries assembled in Zurich at the end of August to attend the first meeting of the International Mineralogical Association and afterwards to go on one of the two field excursions. Many of those present had also attended the foundation meeting of the Association at Madrid in April 1958. There it had been laid down that the Association shall be an association of national mineralogical societies and pursue the aim of furthering the cause of mineralogy in all its aspects. To effect this, technical problems confronting mineralogists will be dealt with by special commissions, while scientific matters will be treated in symposia and eventually in publications sponsored by the Association. 'The commissions (at present numbering four) proceeded to deal with questions relating to abstracts, new minerals, mineral data and museums, while at business meetings the statutes of the Association came up for discussion and amendment. Two symposia were held of which a brief account will be given here. The papers will be printed in extenso in a coming volume of the Estudios Geologicos published by the Instituto "Lucas Mallada" in Madrid.

\section{Alpine Mineral Fissures}

The first symposium, held under the chairmanship of Prof. E. Wenk (Basle), dealt with Alpine mineral fissures. To these may be assigned numerous occur- rences in Switzerland and also some in quite different regions. Prof. R. L. Parker (Zurich) outlined the main features of these deposits as shown by the Swiss localities. Though deservedly called "Alpine", the distribution in the Alps of such occurrences is localized and restricted to areas in which the interplay of mechanical forces and strength properties of the rocks is suitably balanced. The resulting fissures are late- to post-tectonic in formation and filling and show no prolongation in depth. They contain varied mineral assemblages which are considered to have crystallized from solutions deriving their contents from the surrounding rocks. The belief that this process (known as lateral secretion) was widespread in the Alps is supported by the quite general dependence of the fissure contents on the character of the country rock and frequently also by the presence around fissures of a zone of leached rock which seems to have been the source of the matter now contained in the crystallized minerals of the fissure. Among these, quartz and adularia are practically ubiquitous.

The relationship of Alpine fissure minerals to those of the druses in the granite of Baveno was discussed by Prof. G. Fagnani (Milan). That such a comparison may be made is shown by the numerous minerals common to both types of occurrence. These include not only widespread species such as quartz and 
orthoclase but scarcer ones also, and even some like gadolinite and bazzite that are rarities in central Europe. In spite of such similarities, the Alpine fissures and the Baveno geodes actually have little in common. Even the minerals occurring in both show differences in habit which reflect the differing modes of formation. This is especially true of orthoclase, which in the Alpine fissures is always developed as adularia which never appears at Baveno. The Baveno quartz, though well crystallized, lacks the wealth of forms prevalent in the fissures and never shows the Ticino habit with large acute rhombohedra found in some Swiss occurrences. A signifieant paragenetic detail is the appearance of zinnwaldite instead of muscovite as chief mica of the geodes.

Dealing with the origin of quartz as a fissure mineral of the Alpine type in the U.S.S.R., Prof. D. P. Grigoriev (Leningrad) stated that numerous mineral occurrences in the Soviet Union are assigned to the Alpine type of fissure deposit. A reason for doing so is the possibility of establishing definite connexions between the country rock and the mineral parageneses found in the veins and cavities in question. Analytical results obtained on unaltered country rock and on altered specimens from the veins provide corroborative evidence. As a special instance of Alpine-type mineral genesis, Prof. Grigoriev discussed the deriva tion and crystallization of quartz found in veins which are younger than the quartzite rocks in which they occur. Many of the observed peculiarities of Alpine quartz relating to crystal habit, distortion, aggregate development, distribution, etc., have been traced to and explained by such factors as the number, distribution, and exposure of seed crystals, and the physical state of the circulating solutions, which may be saturated in respect to the large seed crystals of quartz while still unsaturated as regards the small ones. The relative rates of crystallization of different minerals were also discussed and prove to be characteristic for a given locality though varying strongly from place to place.

Prof. M. A. Kashkai (Baku) showed that in the Caucasus Mountains (which possess many points of similarity to the Alps) mineral deposits frequently occur which, judged by the applicable criteria, must be considered to be of a nature and formed by processes akin to those of the Alpine fissures. Emphasis was laid on the wide distribution of so-called 'listvenites', which are metamorphic rocks consisting chiefly of quartz, carbonates, and chlorite besides numerous accessory constituents. As these are sometimes formed from hydrothermal solutions, relationships between them and deposits of Alpine type can be established.

Prof. J. Lietz (Hamburg) described experiments he has carried out on small cubes of colourless quartz designed to convert them into smoky quartz by electrolysis. The cubes are placed between electrodes and treated in an electric field of $200-1,500 \mathrm{~V} . / \mathrm{cm}$. at temperatures of $700^{\circ}-900^{\circ} \mathrm{C}$. The arrangement of the electrodes fundamentally affects the results obtained. When the crystallographic axis of the crystal lies in the direction of the field and each electrode completely covers one side of the cube, a front of colour appears at the anode and migrates towards the cathode, thus progressively filling the entire cube. However, when the front has reached the cathode, the cube starts losing colour at the anode and finally becomes colourless again. When the anode only partially covers one side of the cube, the portion of the latter lying immediately in front of the anode is coloured and discoloured as just described; whereas that part of the cube not covered by the anode also assumes an intense dark colour which does not disappear and proves to be thermally stable up to $1,000^{\circ} \mathrm{C}$. The phenomena agree well with the assump. tion that colour centres exist in the quartz lattice in the form of $\left(\mathrm{AlO}_{4 / 2}\right)$ tetrahedra which yield an electron when electrolysed.

Prof. F. Laves (Zurich) spoke on the feldspars of the Alpine fissures and their twinning. While the twins of adularia (potassium-feldspar with up to 10 per cent sodium) consist of a restricted number of individuals, albite (translucent sodium-feldspar) tends towards polysynthetic twins comprising many individuals. Such twinning may be the result of diffusive changes in the distribution of aluminium and silicon in the lattice or of displacive transformations due to a temperature-conditioned collapse of the structure. However, polysynthetic twins sometimes result from mechanical deformation when the distribution of aluminium and silicon is sufficiently disordered. The more opaque milky white variety of albite elongated after the $b$-axis and known as pericline is twinned according to a law usually defined as a rotation of $180^{\circ}$ about the $b$-axis. Investigations show, however, that structural changes must have taken place after twin formation and be the reason why the inter-relation between the crystals only approximates to this law, the 'twin axis' being actually an irrational direction in (001). Leaching of a primary anorthite content and its partial metasomatic replacement by albite substance is a reason for this condition and causes numerous minute voids within the crystals. This accounts for their milky appearance.

\section{Twinning of Crystals}

The second symposium, the chairman of which was Prof. Martin J. Buerger (Cambridge, Mass.), had as its topic the twinning of crystals. Prof. Buerger's own paper was devoted to various aspects of twinning in general but with special regard to the boundaries between the twinned individuals. While the low energy of such junctions is quite generally a most characteristic feature of twins, the latter may be connected either by coherent or incoherent boundaries. A common type of coherent twin results from simple or more general stacking faults in the structure. Fx-solution pairs, however, always have incoherent boundaries. According to Prof. Buerger, twins related by 3 -fold, 4 -fold and 6 -fold rotations are certainly possible.

Dr. H. Curien (Paris), discussing the degree of symmetry which a twin axis may possess, recalled the belief held by Georges Friedel that twin axes may be of a 2-, 3-, 4-, or 6-fold character. Examining each of these possibilities, Dr. Curien considers unlikely those involving 3 - or 6 -fold rotations; for these could not bring about any strict coincidence of lattice planes belonging to the two participating. crystals. An example believed by Friedel to exemplify twinning by such an operation is the sagenite twin of rutile in which three crystals seemingly occupy positions realizable by a $60^{\circ}$ rotation around the $a$-axis. However, this grouping can be accounted for by supposing the well-known twin laws of rutile (reflexion on (011) and (031)) to be both operative. 'They lead to positions deviating by only $10^{\prime}$, that is, by an amount within the experimental error, from the theoretical hexagonal positions. Dr. Curien accepts the possibility of twinning according to 4 -fold axes. 
These will be oriented along lines of intersection between perpendicular planes present in all systems except the triclinic. Such axes will, however, not produce actual coincidence of the nodes of the lattice planes, so that the 'quality' of such twins must be much inferior to that of ordinary ones.

Prof. J. D. H. Donnay (Baltimore) proceeded from the fact established by Georges Friedel that a crystal twins whenever there is a superlattice that has (rigorously or approximately) more symmetry than the actual lattice of the crystal. Similarly, it seems that the presence of an appropriate sub-lattice may lead to twinning. It was then shown that twinning may also be explained in terms of the 'lattice complex' of Paul Niggli. This term is applied to the assemblage of all like atoms in a structure independently of its position in the space group. When such a complex of atoms has more symmetry than the space group as a whole, the remaining atoms can distribute themselves in various ways which are related by symmetry operations belonging to the complex but not to the space group. These are the operations by which certain types of twinning are achieved.

Dr. P. Hartman (Groningen) spoke on the twin of atacamite, the law of which is definable either as a $120^{\circ}$ rotation about the $[950]$ direction or as one of $180^{\circ}$ about [544]. The structural explanation lies, according to Dr. Hartman, in the parallelism of chain links in the structure and not of lattice rows as in ordinary twins. 'This, however, recalls the manner in which erystals of different species sometimes grow together in oriented pairs. This phenomenon is known as epitaxy, and Dr. Hartman suggested that very close relationships exist between it and twinning. This would imply the non-existence of 3-, 4-, and 6-fold twin axes.

Dr. W. T. Holser (La Habra, Cal.) analysed the relations of symmetry and structure at the boundary plane of a twin, extending his investigation to include trans-boundary relations. He re-described Buerger's model of a trans-boundary growth step as a particular type of screw dislocation. Twin stability is related to some measure of fit along the dislocation of the step, which latter may be symmetrical or pseudosymmetrical.

Prof. T. Ito (Tokyo) spoke on twinning as a building principle of crystals and introduced the new concept of 'space groupoids' as distinct from space groups.

Dealing with twinning in diamond, Prof. A Neuhaus (Bonn) first summarized some of the conflicting observations made on this mineral. As a result of his own investigations, he considers it certain that a transition between two modifications takes place but believes that only one is isometric. He assigns this one ( $\alpha$-diamond) to the $\mathrm{O}_{h}$ crystal class while attributing rhombohedral $\left(D_{3} d^{-}\right)$symmetry of pseudo-isometric character to the other ( $\beta$-diamond). Coarsely lamellated diamond seems to have evolved by natural tempering from such material showing finer alternations and arising from the transformation of the original isotropic substance. Thus a distinction must be made between the true double-refraction of $\beta$-diamond and irregular effects due to strains produced by (sub-) microscopic inclusions. Primary $\alpha$-diamond is stable at high pressures and temperatures above $1,500^{\circ} \mathrm{K}$., whereas $\beta$-diamond is stable at lower temperatures. Natural diamonds always belong to the $\beta$-modification and may either have been formed as such from the outset or be the result of a secondary $\alpha-\beta$ transformation. In either case twin lamellæ will be present which are primary in one and secondary (mimetic) in the other. Prof. Neuhaus demonstrated a new phase diagram of carbon from which conclusions regarding the stable formation of diamond can be drawn and the differences between Type-1 and II diamonds explained.

Dr. I. Sunagawa (Tokyo) described the growth and natural etch patterns observed with a phase-contrast microscope on the boundaries of hematite crystals forming contact twins after (10) 0$)$. The surface structures of the twin boundaries are difficult to explain as simple junctions in twin position effected during growth. It seems, rather, that the mechanism of contact twinning involves processes of faulting or slipping of the participating lattices.

\section{Robert L. Parker}

\section{SCHOOL OF PHYSICS WITHIN THE UNIVERSITY OF SYDNEY}

$\mathrm{T}$ $\mathrm{HE}$ research activities and student numbers of the School of Physics within the University of Sydney, the head of which is Prof. H. Messel, have expanded so much during the past six years that a major reorganization has become necessary.

Henceforth there will be five departments within the School; the newly created departments are: (1) The Basser Computing Department; (2) The Daily Telegraph Theoretical Department; (3) The Falkiner Nuclear Department; (4) The Wills Thermonuclear Department; (5) The Chatterton Astronomy Department.

The Basser Computing Department arises from the Adolph Basser Computing Laboratory with the electronic digital computer, Silliac I. This computer has been a great success in Australia and largely responsible for opening up the computing field there. Opened on July 1, 1956, Silliac I has run at high reliability since that date, and at present is occupied $24 \mathrm{hr}$. a day on a three-shift basis. Work has or is being carried out for every University in Australia, two in New Zealand, for 20 government and semi- government organizations, and 87 private organizations. Some two hundred personnel throughout the country have attended courses on the computer and a postgraduate diploma course in automatic computing has been established.

Steps are now being taken to proceed with the construction of a much faster transistorized machine. Silliac I was constructed using the University cf Illinois design of Illiac. The new computer in the Basser Department is likely to use the design of the new fast computer at present being built by the Illinois group. The present cost is estimated at fA.575,000. These funds have still to be provided.

Dr. John M. Bennett is in charge of numerical analysis and the user end of Silliac I, while Mr. B. E. Swire is chief engineer.

The Daily Telegraph Theoretical Department was established with a gift of $£ A .50,000$ from Consolidated. Press, Ltd. The theoretical group which forms the basis of the newly created department always has been a strong one. The appointment of Prof. S. T. Butler to the chair of theoretical physics should do 